\title{
Evolution of herbicide resistance in weeds: initial frequency of target site-based resistance to acetolactate synthase-inhibiting herbicides in Lolium rigidum
}

\author{
C Preston ${ }^{1}$ and SB Powles ${ }^{2}$ \\ ${ }^{1}$ CRC for Weed Management Systems and Department of Applied and Molecular Ecology, Waite Campus, University of Adelaide, \\ SA, Australia; ${ }^{2}$ Western Australian Herbicide Resistance Initiative, Faculty of Agriculture, University of Western Australia, \\ Nedlands, WA, Australia
}

The frequency of individuals resistant to two acetolactate synthase (ALS)-inhibiting herbicides in three previously untreated populations of Lolium rigidum was determined. The frequency of individuals resistant to the sulfonylurea herbicide sulfometuron-methyl varied from $2.2 \times 10^{-5}$ to 1.2 $\times 10^{-4}$ and the frequency of individuals resistant to the imidazolinone herbicide imazapyr varied from $1 \times 10^{-5}$ to $5.8 \times$ $10^{-5}$ depending on the population. Application of sulfometu- ron-methyl selected individuals with a herbicide-insensitive ALS, which was also cross-resistant to imazapyr. The high initial frequency of individuals resistant to ALS-inhibiting herbicides in $L$. rigidum populations never previously exposed to these herbicides helps explain the rapid evolution of herbicide resistance in this species once ALSinhibiting herbicides were used.

Heredity (2002) 88, 8-13. DOI: 10.1038/sj/hdy/6800004

Keywords: Lolium rigidum; herbicide resistance; resistance evolution; sulfometuron-methyl; imazapyr; acetolactate synthase

\section{Introduction}

Herbicides are used extensively for weed control in crop and fibre production systems throughout the world. One consequence of the extensive use of herbicides has been the appearance of herbicide resistance in weed species. Currently herbicide resistance has appeared in more than 140 weed species and many thousands of crop fields worldwide (Heap, 1999). Herbicide resistance is known in all areas where herbicides are used intensively (Powles et al, 1997). Major factors influence the evolution of herbicide resistance, including the intensity of selection by herbicides and the initial frequency of herbicide resistant individuals in the population (reviewed by Jasieniuk et al, 1996). The first factor is relatively easy to determine, but there is little information pertaining to the initial frequency of herbicide resistant individuals in weed populations (Maxwell and Mortimer, 1994; Jasieniuk et al, 1996).

In Australia, Lolium rigidum is a major annual grass weed of cropping systems. This species was introduced into Australia in the $19^{\text {th }}$ century and is now present at high densities across vast areas. L. rigidum reduces crop yields dramatically at high densities and is a major target of herbicides in this area. Herbicide resistance first

Correspondence: C Preston, CRC for Weed Management Systems and Department of Applied and Molecular Ecology, Waite Campus, University of Adelaide, PMB 1 Glen Osmond SA 5064, Australia.

E-mail: christopher.preston@adelaide.edu.au

Received 17 October 2000; accepted 2 July 2001 appeared in L. rigidum in 1980 (Heap and Knight, 1982) and is now widespread across the more intensively cropped regions of southern Australia (Preston et al, 1999). In some areas more than $40 \%$ of cropping fields are infested with herbicide-resistant $L$. rigidum populations (Nietschke et al, 1996). Multiple herbicide resistant populations of $L$. rigidum can be simultaneously resistant to herbicides from more than 12 herbicide chemistries representing seven modes of action (Hall et al, 1994; Preston et al, 1996). The majority of cases of herbicide resistance in $L$. rigidum populations are to herbicides that inhibit acetyl-coenzyme A carboxylase (ACCase) or acetolactate synthase (ALS). One unusual aspect of herbicide resistance in southern Australia has been the rapid evolution of resistance. Resistance to both ACCase- and ALSinhibiting herbicides has occurred with as few as three applications of these herbicides (Tardif et al, 1993; Powles et al, 1997; Preston et al, 1999). Gill (1995) established that of the L. rigidum populations sent for testing for herbicide resistance, all receiving four or more applications of ALSinhibiting herbicides, were resistant to these herbicides.

Two major mechanisms endowing resistance to ALSinhibiting herbicides in L. rigidum have been established, a modified ALS or enhanced metabolism of herbicides (Christopher et al, 1992). The latter mechanism is correlated with cross-resistance selected by ACCase-inhibiting herbicides (Christopher et al, 1991). Populations of L. rigidum with metabolism-based resistance to ALS-inhibiting herbicides are not resistant to sulfometuron-methyl or imazapyr (Christopher et al, 1991). Gill (1995) demonstrated that most populations of $L$. rigidum resistant to 
ALS-inhibiting herbicides were also resistant to sulfometuron-methyl and, therefore, probably contained a herbicide-resistant ALS.

The rate of spontaneous mutations to resistance to ALS-inhibiting herbicides has been estimated at $1 \times 10^{-9}$ in Arabidopsis thaliana (Haughn and Somerville, 1987) and at about $2.7 \times 10^{-8}$ in Nicotiana tabacum cell cultures (Harms and DiMaio, 1991). Depending on the relative fitness of the resistant individuals, the actual frequency of resistant individuals in a natural population is likely to be up to two orders of magnitude higher than the mutation frequency (Jasieniuk et al, 1996). The aim of this study was to determine the initial frequency of resistance to ALS-inhibiting herbicides in L. rigidum so as to understand the rapid evolution of resistance to these herbicides.

\section{Materials and methods}

\section{Plant material}

Three susceptible populations of L. rigidum were used in this study. Population 1 was from a pasture in western Victoria where no herbicides had been used. This population had never been exposed to ALS-inhibiting herbicides and has been in our collection since 1988, well before the first reports of widespread resistance to ALSinhibiting herbicides in Australia. Before 1990, no examples of target site-based resistance were known in Australia (Christopher et al, 1992). The other two populations were obtained from the south-east of South Australia. Population 2 was obtained in 1990 from an organic field where herbicides had never been used. Population 3 was obtained in 1996 from a field where tillage was used to control weeds and the only herbicide exposure this population had received was occasional application of paraquat in pastures. Paraquat acts as a radical generating herbicide through accepting electrons at photosystem I and cross resistance between paraquat and ALS inhibitors is neither known nor expected (Preston, 1994). The original seed was collected by commercial harvesting equipment, either directly (population 1) or as screenings from harvesting of grain (populations 2 and 3). Each sample came from a single field with more than $50 \mathrm{~kg}$ of seed in each sample.

\section{Field selection experiment}

A field experiment was conducted at Roseworthy, South Australia during the winter of 1994 . An area of $90 \times 40$ $\mathrm{m}$ was sown to L. rigidum population 1 . A stand of about 350 plants $/ \mathrm{m}^{2}$ was established. The area was divided into four plots of $20 \times 45 \mathrm{~m}$ and each plot further subdivided into a smaller subplot of $20 \times 13.75 \mathrm{~m}$ and a larger subplot of $20 \times 31.25 \mathrm{~m}$. Herbicide was applied to the plots 6 weeks after sowing, when plants were at the three-leaf to two-tiller stage. A commercial formulation of sulfometuron-methyl was applied at two rates of 4 or $16 \mathrm{~g} / \mathrm{ha}$. The high rate was applied once to the smaller subplot and four applications of the low rate were applied, about 3 weeks apart to the large subplots. Therefore, both treatments received a total of $16 \mathrm{~g} / \mathrm{ha}$ sulfometuron-methyl. The herbicide was applied by motorbike fitted with a 6 $\mathrm{m}$ boom applying $67 \mathrm{l} / \mathrm{ha}$ of water. All plots were sprayed with two passes each at half of the stated rate. Thirteen weeks after application of the first herbicide treatment, survivors were assessed. Plants with at least five fertile tillers were counted as survivors and transplanted into plots. These individuals were grouped by treatment and allowed to cross-pollinate. Some smaller plants present in some plots were assumed to be later germinating seedlings and were not collected.

\section{Laboratory selection experiment}

Seedling germination on agar containing sulfometuronmethyl is an effective way of identifying individuals with a herbicide-resistant ALS (Burnet et al, 1994). Agar (100 ml) containing $30 \mu \mathrm{M}$ sulfometuron-methyl was set in 1 litre plastic containers with 50 containers per replicate and four replicates spaced in time. Exactly $4 \mathrm{~g}$ of L. rigidum seed was placed in each container, as well as in a control container with herbicide-free agar. The containers were placed in a germination cabinet set at $19^{\circ} \mathrm{C}$ with a $12 \mathrm{~h}, 30 \mu \mathrm{E} / \mathrm{m}^{2} \mathrm{~s}$ light period and a $12 \mathrm{~h}$ dark period for 6 days. The expected number of germinants from $4 \mathrm{~g}$ of seed was calculated from the container without herbicide. Four replicates of this experiment were conducted for each $L$. rigidum population. Imazapyr can be used to select for resistant individuals in the same way (Preston C, unpublished results). Therefore, a second selection experiment was conducted using $100 \mu \mathrm{M}$ imazapyr as the selecting herbicide.

Seedlings that had a green leaf extending through the coleoptile were transplanted to pots containing potting soil and placed in a growth room with a $19^{\circ} \mathrm{C}, 12 \mathrm{~h}, 300$ $\mu \mathrm{E} / \mathrm{m}^{2} \mathrm{~s}$ light period and a $15^{\circ} \mathrm{C}, 12 \mathrm{~h}$ dark period. In addition, for each replicate of each population, one pot containing 12 unselected seedlings was also transplanted. At the two- to three-leaf stage, plants were treated with $16 \mathrm{~g} / \mathrm{ha}$ of a commercial formulation of sulfometuronmethyl containing $0.2 \%$ non-ionic surfactant or $25 \mathrm{~g} / \mathrm{ha}$ of a commercial formulation of imazapyr. Herbicide was applied using a laboratory spray cabinet fitted with flatfan nozzles and an output of 130 1/ha. Following herbicide application, plants were returned to the growth room and assessed for survival after 21 days. Surviving plants from the sulfometuron-methyl selection were grouped by population and just before flowering were placed outdoors, surrounded by plastic sheeting and allowed to cross pollinate.

\section{Heritability of resistance}

Two separate measures were made to determine whether the individuals selected by the herbicide treatments carried a heritable resistance trait.

Seeds (1.5 or $0.3 \mathrm{~g}$ ) obtained from plants selected in the field or the laboratory and allowed to cross within selections, were placed on agar containing $30 \mu \mathrm{M}$ sulfometuron-methyl. An equivalent weight of seed was placed on agar without herbicide as a control. The seed was placed in the germination cabinet. After 6 days, the numbers of seedlings with a green leaf protruding through the coleoptile were counted. As target site-based resistance to ALS-inhibiting herbicides is inherited as a single, largely dominant gene (Shaner, 1999), it is expected the progeny will segregate 3:1 for resistance. The results were compared with the expected segregation using a $\chi^{2}$ test.

A second experiment examined whether resistance to sulfometuron-methyl and imazapyr were being selected together. For this experiment, progeny of sulfometuron- 
methyl or imazapyr laboratory selections were germinated, planted into pots and grown outdoors. When plants had reached the four- to five-tiller stage, each plant was divided it two. The two clones were trimmed to 1 $\mathrm{cm}$ of root and $2 \mathrm{~cm}$ of shoot and planted in separate pots. When the clones had recovered and produced 5 to $7 \mathrm{~cm}$ of new leaf growth they were sprayed with herbicide. One clone of each plant was treated with $16 \mathrm{~g} / \mathrm{ha}$ of a commercial formulation of sulfometuron-methyl containing $0.2 \%$ non-ionic surfactant and one plant with 25 $\mathrm{g} /$ ha of a commercial formulation of imazapyr. Herbicides were applied using the laboratory spray cabinet. Plants were returned outdoors and assessed for survival after 21 days. Plants were counted as alive if they had produced new green leaf tissue since spraying. Each plant was assessed for survival to sulfometuron-methyl and imazapyr.

\section{ALS assay}

Seeds obtained from the plants selected in the field or the laboratory were placed on agar containing $30 \mu \mathrm{M}$ sulfometuron-methyl. After 6 days, germinated seedlings were transplanted to soil and grown in a growth room set at $19^{\circ} \mathrm{C}, 12 \mathrm{~h}, 400 \mu \mathrm{E} / \mathrm{m}^{2} \mathrm{~s}$ light and $15^{\circ} \mathrm{C}, 12 \mathrm{~h}$ dark regime for 3 weeks. Leaves ( $3 \mathrm{~g}$ ) were harvested and ground in a cold mortar in $3 \mathrm{ml}$ of ice-cold Buffer A (100 $\mathrm{mM}$ potassium phosphate buffer ( $\mathrm{pH} 7.5), 1 \mathrm{mM} \mathrm{MgCl}$, $0.5 \mathrm{mM}$ thiamine pyrophosphate, $10 \mu \mathrm{M}$ flavin adenine dinucleotide, $1 \mathrm{mM}$ dithiothreitol, $1 \mathrm{mM}$ phenylmethylsulfonyl fluoride and $1 \mathrm{mM}$ sodium pyruvate) with 5 $\mathrm{mg} / \mathrm{ml}$ insoluble polyvinylpyrrolidone, and a small amount of acid-washed sand. The slurry was transferred to a centrifuge tube and the mortar washed with a further $3 \mathrm{ml}$ of Buffer A. The solution was centrifuged at 20000 $g$ for $10 \mathrm{~min}$ and the supernatant brought to $50 \%$ saturation with $\left(\mathrm{NH}_{4}\right)_{2} \mathrm{SO}_{4}$. The solution was stirred for 30 minutes on ice, centrifuged at $20000 \mathrm{~g}$ for $30 \mathrm{~min}$ and the pellet resuspended in $0.5 \mathrm{ml}$ of Buffer A without dithiothreitol or phenylmethylsulfonyl fluoride. This solution was desalted on a Sephadex G9 column previously equilibrated with Buffer B (100 mM potassium phosphate buffer ( $\mathrm{pH} 7.0), 200 \mathrm{mM}$ sodium pyruvate, $20 \mathrm{mM} \mathrm{MgCl}_{2}$, $2 \mathrm{mM}$ thiamine pyrophosphate and $20 \mu \mathrm{M}$ flavanin adenine dinucleotide) and the protein collected in $2 \mathrm{ml}$ Buffer B. The partially purified protein was assayed for ALS activity in the presence of sulfometuron-methyl or imazapyr in $400 \mu \mathrm{l}$ well microtitre plates. To each well, $50 \mu \mathrm{l}$ of herbicide solution containing twice the desired final concentration was added. Wells 1 and 7 in each row contained water and $20 \mu \mathrm{l}$ of $6 \mathrm{~N} \mathrm{H}_{2} \mathrm{SO}_{4}$ was added to well 7 to inactivate the enzyme. The reaction was started by addition of $50 \mu \mathrm{l}$ of enzyme extract and incubated for 30 $\min$ at $37^{\circ} \mathrm{C}$. The reaction was stopped by addition of $20 \mu \mathrm{l}$ of $6 \mathrm{~N} \mathrm{H}_{2} \mathrm{SO}_{4}$, which also served to decarboxylate acetolactate to acetoin. The decarboxylation reaction was allowed to proceed for $15 \mathrm{~min}$ at $60^{\circ} \mathrm{C}$. Colour development occurred following the sequential additions of 95 $\mu \mathrm{l} 0.55 \%$ creatine and $95 \mu \mathrm{l} 5.5 \% \quad \alpha$-naphthol in $5 \mathrm{~N}$ $\mathrm{NaOH}$ and incubation at $60^{\circ} \mathrm{C}$ for $15 \mathrm{~min}$. Duplicate samples were pooled and absorption measured at 530 nm. Absorption occurring in the samples where $\mathrm{H}_{2} \mathrm{SO}_{4}$ was added before the assay was subtracted from the absorption of all other samples. ALS activity in the presence of herbicide was calculated as percentage of activity in the absence of herbicide.

\section{Results}

\section{Field selection}

About $1.12 \times 10^{6}$ herbicide susceptible L. rigidum plants (population 1) were treated with four applications of 4 $\mathrm{g} /$ ha (total of $16 \mathrm{~g} / \mathrm{ha}$ ) of sulfometuron-methyl and 3.7 $\times 10^{5}$ plants with a single application of $16 \mathrm{~g} / \mathrm{ha}$ of sulfometuron-methyl. The herbicide caused massive mortality; however, there were some survivors. A total of 139 plants survived the lower rates of sulfometuron-methyl and 46 survived the single application of the higher rate. The average proportion of survivors was similar for the two treatments at $1.2 \times 10^{-4}$ (Table 1$)$.

\section{Laboratory selection}

The vast majority of seeds placed on agar containing sulfometuron-methyl or imazapyr failed to germinate. However, between 700 and 1000 seedlings were recovered from $4 \mathrm{~g}$ of seed placed on the herbicide-free agar. Between 10 and 70 seedlings with green shoots emerging from the coleoptiles were transplanted to soil for each population in each replicate of the experiment. However, most of these seedlings did not grow in soil, probably because the meristematic region had already been killed by herbicide. Those individuals that did grow were subsequently treated with $16 \mathrm{~g} /$ ha sulfometuron-methyl or $25 \mathrm{~g} / \mathrm{ha}$ imazapyr when at the two-leaf stage and all survived, whereas no unselected seedlings survived this treatment. For sulfometuron-methyl, there were 12 survivors from an expected $2 \times 10^{5}$ germinants from population 1, 16 survivors from an expected $1.6 \times 10^{5}$ germinants from population 2, and three survivors from an expected $1.5 \times 10^{5}$ germinants from population 3 over all replicates. The frequency of survivors was variable between populations in this experiment and ranged from $2.2 \times 10^{-5}$ to $1.1 \times 10^{-4}$ (Table 1 ). For imazapyr there were fewer survivors. Population 1 had three survivors from an expected $2.2 \times 10^{5}$ germinants, population 2 had 11 survivors from an expected $2 \times 10^{5}$ germinants, and population 3 had two survivors from an expected $1.6 \times$ $10^{5}$ germinants. The frequency of survivors to imazapyr varied from $1 \times 10^{-5}$ to $5.8 \times 10^{-5}$ between populations (Table 1).

\section{Heritability of resistance}

A considerable amount of seed was set by the survivors of the field selection. However, as a result of differences in flowering time of sulfometuron-methyl-resistant individuals, only a few seeds were set on survivors of populations 1 and 2 and none on survivors from population 3 from the laboratory selection. Likewise, only a few seeds were set on imazapyr survivors of populations 2 and 3 and none on population 1. Assessment of heritability of sulfometuron-methyl resistance occurred following germinating seed on agar containing $30 \mu \mathrm{M}$ sulfometuron-methyl.

In all cases, seed germination ranged from 65 to $80 \%$ of germination on agar without herbicide (Table 2). Survivorship of the laboratory selections fit a 3:1 ratio of resistant to susceptible, suggesting a single dominant gene encodes resistance. Survivorship of the field selections did not fit this ratio and was lower than for the survivors of the laboratory selection. This suggests that a few susceptible escapes or individuals with less effective resistance may have survived in the field selection, com- 
Table 1 Frequency of survivors of sulfometuron-methyl or imazapyr selection in L. rigidum populations

\begin{tabular}{lcc} 
Population & Selection treatment & Frequency of survivors \\
\hline Field experiments & & \\
Population 1 & $4 \times 4 \mathrm{~g} /$ ha sulfometuron-methyl & $1.24 \times 10^{-4} \pm 7.8 \times 10^{-6}$ \\
Population 1 & $16 \mathrm{~g} /$ ha sulfometuron-methyl & $1.24 \times 10^{-4} \pm 1.4 \times 10^{-5}$ \\
Laboratory experiments & & \\
Population 1 & $30 \mu \mathrm{M}$ sulfometuron-methyl & $4.6 \times 10^{-5} \pm 3.1 \times 10^{-5}$ \\
Population 1 & $100 \mu \mathrm{M}$ imazapyr & $1.0 \times 10^{-5} \pm 0.6 \times 10^{-6}$ \\
Population 2 & $30 \mu \mathrm{M}$ sulfometuron-methyl & $1.08 \times 10^{-4} \pm 1.9 \times 10^{-5}$ \\
Population 2 & $100 \mu \mathrm{M}$ imazapyr & $5.8 \times 10^{-5} \pm 2.3 \times 10^{-5}$ \\
Population 3 & $30 \mu \mathrm{M}$ sulfometuron-methyl & $2.2 \times 10^{-5} \pm 1.2 \times 10^{-5}$ \\
Population 3 & $100 \mu \mathrm{M}$ imazapyr & $1.4 \times 10^{-5} \pm 0.8 \times 10^{-6}$
\end{tabular}

Populations were selected in the field or the laboratory with discriminating rates of herbicides. Values are means \pm s.e. of four plots.

Table 2 Chi-square analysis of segregation for sulfometuron-methyl resistance in progeny of sulfometuron-methyl selections

\begin{tabular}{lccc}
\hline $\begin{array}{l}\text { Population and selection with sulfometuron- } \\
\text { methyl }\end{array}$ & $\begin{array}{c}\text { Germinants } \\
\text { (control) }\end{array}$ & $\begin{array}{c}\text { Germinants } \\
(30 \mu M \text { sulfometuron-methyl) }\end{array}$ & $\begin{array}{c}\chi^{2} \text { probability } \\
(3: 1 \text { ratio) }\end{array}$ \\
\hline Population 116 g field selection & 290 & 190 & 0.0002 \\
Population 1 $4 \times 4$ g field selection & 211 & 142 & 0.01 \\
Population 1 laboratory selection & 48 & 37 & 0.74 \\
Population 2 laboratory selection & 68 & 54 & 0.40 \\
\hline
\end{tabular}

Seed (1.5 g or $0.3 \mathrm{~g}$ ) was sown on agar or agar containing $30 \mu \mathrm{M}$ sulfometuron-methyl.

pared with the laboratory selection. From the frequency of resistance in the progeny, it is estimated that as many as $8 \%$ of the plants collected from the field experiment may have been susceptible escapes.

When progeny of survivors of laboratory selections were examined for resistance to sulfometuron-methyl and imazapyr, only two phenotypes were observed. Plants were either resistant to sulfometuron-methyl and imazapyr or susceptible to both herbicides (Table 3). This result suggests that a single allele provides resistance to both herbicides in the selected populations.

\section{ALS assay}

As expected, the ALS enzyme extracted from the herbicide-susceptible $L$. rigidum population 1 was highly susceptible to the herbicides sulfometuron-methyl and imazapyr in vitro (Figure 1). ALS enzyme activity was greatly inhibited by $1 \mu \mathrm{M}$ sulfometuron-methyl and $100 \mu \mathrm{M}$ imazapyr. Susceptibility of ALS activity from the progeny of survivors of the field experiment was also measured. As the survivors of the herbicide treatment are expected to be heterozygous for the resistance gene, the progeny would be expected to segregate for resistance. Therefore,

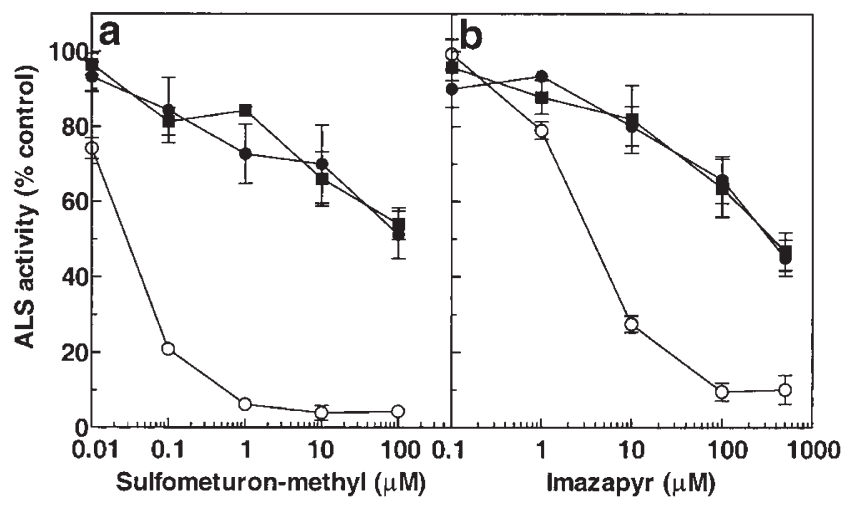

Figure 1 Response to sulfometuron-methyl (a) and imazapyr (b) in vitro of ALS isolated from population $1(\mathrm{O})$, and sulfometuronmethyl resistant progeny of the $4 \times 4 \mathrm{~g} / \mathrm{ha}(\bullet)$ and $16 \mathrm{~g} / \mathrm{ha}($ selections from population 1. Each point is the mean \pm s.e. of three determinations.

Table 3 Phenotypes of individual plants from progeny of survivors of the laboratory selection regime

\begin{tabular}{lcr}
\hline Population and selection & $\begin{array}{c}\text { Plants susceptible to } \\
\text { sulfometuron-methyl and imazapyr }\end{array}$ & $\begin{array}{c}\text { Plants resith } \\
\text { sulfometuron-met }\end{array}$ \\
\hline Population 1 Sulfometuron-methyl & 9 & 36 \\
Population 2 Sulfometuron-methyl & 8 & 32 \\
Population 2 Imazapyr & 9 & 26 \\
Population 3 Imazapyr & 6 & 17
\end{tabular}

Individual plants were cloned into two and clones treated with either $15 \mathrm{~g} /$ ha sulfometuron-methyl or $25 \mathrm{~g} / \mathrm{ha}$ imazapyr. No individuals were resistant to only one herbicide. 


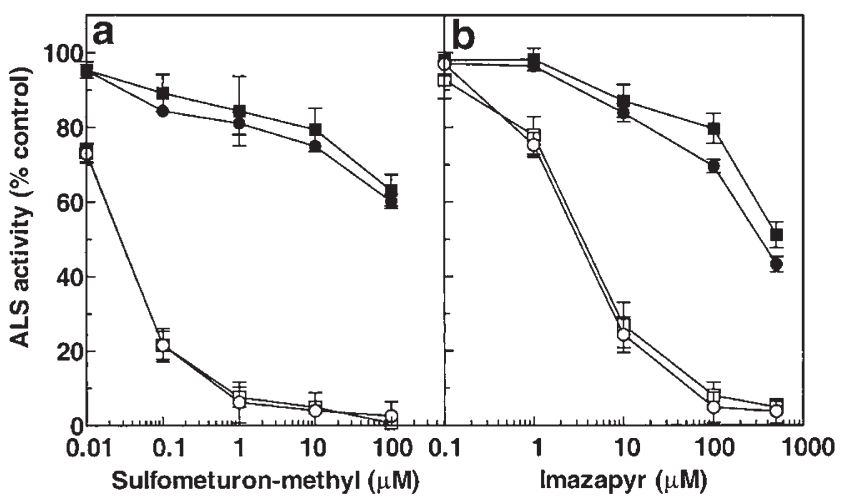

Figure 2 Response to sulfometuron-methyl (a) and imazapyr (b) in vitro of ALS isolated from population $1(\bigcirc)$, population $2(\square)$, and sulfometuron-methyl-resistant progeny of the selections from population $1(\mathbf{O})$ and population $2(\mathbb{\square})$. Each point is the mean \pm s.e. of three determinations.

seeds were germinated on agar containing $30 \mu \mathrm{M}$ sulfometuron-methyl to remove susceptible individuals. Enzyme was extracted from leaves of survivors and assayed for susceptibility to herbicides. For both the $4 \times$ $4 \mathrm{~g} / \mathrm{ha}$ and $16 \mathrm{~g} /$ ha sulfometuron-methyl selections, ALS activity was found to be highly resistant to sulfometuronmethyl and imazapyr (Figure 1). The level of resistance to sulfometuron-methyl and imazapyr was almost the same for both selections. Therefore, it is highly likely that the $4 \times 4 \mathrm{~g} / \mathrm{ha}$ and $1 \times 16 \mathrm{~g} /$ ha sulfometuron-methyl selections provided identical selection pressures.

Sulfometuron-methyl- and imazapyr-inhibited ALS isolated from the susceptible populations 1 and 2 with similar inhibition kinetics (Figure 2). In contrast, ALS isolated from progeny of the laboratory selections from populations 1 and 2 were highly resistant to both sulfometuron-methyl and imazapyr. There was little difference in the level of resistance to sulfometuron-methyl between the resistant selections. However, ALS isolated from the population 2 selection was slightly more resistant to imazapyr (Figure 2).

\section{Discussion}

This study has established that in natural populations of L. rigidum the frequency of individuals with an ALS enzyme resistant to the sulfonylurea herbicide sulfometuron-methyl ranges between $4.6 \times 10^{-5}$ and $1.2 \times 10^{-4}$. In the same populations the frequency of individuals resistant to the imidazolinone herbicide imazapyr ranges between $1 \times 10^{-5}$ and $5.8 \times 10^{-5}$. There were small differences in the frequency of sulfometuron-methyl resistant individuals observed in population 1 between the field experiment and the laboratory experiment (Table 1). This difference may be a result of different intensities of selection between the field and laboratory experiments. The sulfometuron-methyl selections from populations 1 and 2 also contained individuals resistant to imazapyr (Figures 1 and 2). As survivorship to sulfometuron and imazapyr within populations was not significantly different ( $t$ test), it seems likely that both herbicides selected mutations providing resistance to both herbicides. The linked inheritance of resistance to sulfometuron-methyl and imazapyr (Table 3 ) supports this conclusion.

The frequency of herbicide-resistant individuals in weed populations is generally assumed to be about $10^{-6}$ (Maxwell and Mortimer, 1994). However, there is no reason that this value should be uniform across herbicide modes of action. Indeed as demonstrated here for L. rigidum, resistance to ALS-inhibiting herbicides is up to 100 times more frequent. In a large population the equilibrium frequency of resistance is dependent on the mutation frequency and the fitness of the resistant mutation. The relationship for a partially or fully dominant gene is described by:

$$
q_{e}=\mu / h s
$$

where $q_{e}$ is the equilibrium frequency of resistant alleles, $\mu$ is the mutation frequency, $h$ the degree of dominance, and $s$ the fitness differential of the resistant allele in the absence of herbicide (Jasieniuk et al, 1996). Assuming that the mutation frequency of $10^{-8}$ to $10^{-9}$, calculated from selection experiments with Arabidopsis thaliana (Haughn and Somerville, 1987) and tobacco cell cultures (Harms and DiMaio, 1991), is similar in L. rigidum, then the resistant individuals should carry a fitness penalty of $0.01 \%$ compared with susceptible individuals. This is consistent with the lack of a measurable fitness penalty in plants containing mutations conferring resistance to ALSinhibiting herbicides (Holt and Thill, 1994).

This study has exposed a surprisingly high frequency of individuals resistant to ALS-inhibiting herbicides in $L$. rigidum populations. It is possible that the high frequency of resistant individuals detected in the L. rigidum populations may have occurred by gene flow from outside the field. However, the fact that the frequencies of resistance in the three populations were similar, despite the populations being collected over 8 years during which time the incidence of resistance to these herbicides went from unknown to a major problem in Australia, argues against gene flow being important.

Mackenzie et al (1997) performed a similar selection experiment on a commercial line of $L$. perenne using chlorsulfuron as the selecting agent and applying selection intensities to obtain 90 or $99.99 \%$ mortality of susceptible individuals. At the lower selection intensity the frequency of putative resistant individuals was $4 \times 10^{-4}$ and at the higher selection intensity ranged from undetected to $3 \times 10^{-5}$. In the study of Mackenzie et al (1997), the selected individuals did not contain a herbicideinsensitive ALS enzyme unlike the present study. Another study has determined high frequencies of individuals resistant to the Photosystem II-inhibiting triazine herbicides in Chenopodium album populations from private gardens in France (Darmency and Gasquez, 1990). However, in that case the relationship between the high initial frequency of resistance and the evolution of resistance in the field was not apparent.

Selection experiments using cell cultures in the absence of mutator chemicals have observed resistance cell lines at frequencies of $10^{-7}$ in cotton (Rajasekaran et al, 1996) and $5 \times 10^{-8}$ in tobacco (Harms and DiMaio, 1991). As cell cultures are grown over a limited number of generations, the frequencies measured are likely to be closer to the mutation frequency than to the equilibrium frequency of resistant alleles.

This research may also have implications for selection in other systems. For example, selection for metal tolerance in plants occurs on old mine sites. Major genes contribute to some examples of metal tolerance and must be 
present within populations for selection to occur (Macnair, 1993). Studies have demonstrated that some plant populations will evolve metal tolerance at some sites and not others (Al-Hiyaly et al, 1993). As rare genes will not be present in all small populations, large populations or a large number of populations will need to be treated to select for these rare genes.

A high initial gene frequency of resistant individuals within a population means that herbicide resistance will develop rapidly once herbicides are used. This has been the experience in L. rigidum, where all populations tested that had been exposed to four or more applications of sulfonylurea herbicides had more than $20 \%$ of individuals with resistance to triasulfuron (Gill, 1995). Had the initial frequency of resistant individuals been known before the introduction of the sulfonylurea herbicides, then the rapid evolution of resistance to these products could have been predicted and managed.

\section{Acknowledgements}

We are grateful for the technical assistance of Mr R Llewellyn in conducting the field experiments.

\section{References}

Al-Hiyaly SA, McNeilly T, Bradshaw AD, Mortimer AM (1993). The effect of zinc contamination from electricity pylons. Genetic constraints on selection for zinc tolerance. Heredity $\mathbf{7 0}$ 22-32.

Burnet MWM, Christopher JT, Holtum JAM, Powles SB (1994). Identification of two mechanisms of sulfonylurea resistance within one population of rigid ryegrass (Lolium rigidum) using a selective germination medium. Weed Sci 42: 468-473.

Christopher JT, Powles SB, Holtum JAM (1992). Resistance to acetolactate synthase-inhibiting herbicides in annual ryegrass (Lolium rigidum) involves at least two mechanisms. Plant Physiol 100: 1909-1913.

Christopher JT, Powles SB, Liljegren DR, Holtum JAM (1991). Cross-resistance to herbicides in annual ryegrass (Lolium rigidum). II. Chlorsulfuron resistance involves a wheat-like detoxification system. Plant Physiol 95: 1036-1043.

Darmency H, Gasquez J (1990). Appearance and spread of triazine resistance in common lambsquarters (Chenopodium album). Weed Technol 4: 173-177.

Gill GS (1995). Development of herbicide resistance in annual ryegrass populations (Lolium rigidum Gaud.) in the cropping belt of Western Australia. Aust J Exp Agric 35: 67-72.

Hall LM, Holtum JAM, Powles SB (1994). Mechanisms responsible for cross resistance and multiple resistance. In: Powles SB, Holtum JAM (eds). Herbicide Resistance in Plants: Biology and Biochemistry, Lewis Publishers: Boca Raton, FL, pp 243261.

Harms CT, DiMaio JJ (1991). Primisulfuron herbicide-resistant tobacco cell lines. Application of fluctuation test design to in vitro mutant selection with plant cells. J Plant Physiol 137: 513-519.
Haughn G, Somerville CR (1987). Selection for herbicide resistance at the whole plant level. In: LeBaron HM, Mumma RO, Honeycutt RC, Duesing JH (eds). Biotechnology in Agricultural Chemistry, American Chemical Society: Washington, DC, pp 98-107.

Heap IM (1999). International survey of herbicide-resistant weeds: lessons and implications. In: The 1999 Brighton Conference - Weeds, British Crop Protection Council: Farnham, UK, pp 769-776.

Heap J, Knight R (1982). A population of ryegrass tolerant to the herbicide diclofop-methyl. J Aust Inst Agric Sci 48: 156-157.

Holt JS, Thill DC (1994). Growth and productivity of resistant plants. In: Powles SB, Holtum JAM (eds). Herbicide Resistance in Plants: Biology and Biochemistry, Lewis Publishers: Boca Raton, FL, pp 299-316.

Jasieniuk M, Brûlé-Babel AL, Morrison IN (1996). The evolution and genetics of herbicide resistance in weeds. Weed Sci 44: 176-193.

Mackenzie R, Mortimer AM, Putwain PD, Bryan IB, Hawkes TR (1997). The potential for the evolution of herbicide resistance: selection, characterisation and polygenic inheritance of resistance to chlorsulfuron in perennial ryegrass. In: De Prado R, Jorrín J, García-Torres L (eds). Weed and Crop Resistance to Herbicides, Kluwer Academic Publishers: Dordrecht, pp 207213.

Macnair MR (1993). The genetics of metal tolerance in vascular plants. New Phytol 124: 541-559.

Maxwell BD, Mortimer AM (1994). Selection for herbicide resistance. In: Powles SB, Holtum JAM (eds). Herbicide Resistance in Plants: Biology and Biochemistry, Lewis Publishers: Boca Raton, FL, pp 1-25.

Nietschke BS, Llewellyn RS, Reeves TG, Matthews JM, Powles SB (1996). Survey of herbicide resistance in ryegrass and wild oats. In: Proceedings of the 8th Australian Agronomy Conference, Australian Society of Agronomy, Melbourne, Australia, p 691.

Powles SB, Preston C, Bryan IB, Jutsum AR (1997). Herbicide resistance: impact and management. Adv Agron 58: 57-93.

Preston C (1994). Resistance to Photosystem I inhibiting herbicides. In: Powles SB, Holtum JAM (eds). Herbicide Resistance In Plants: Biology and Biochemistry, Lewis Publishers: Boca Raton, Fl, pp 61-82.

Preston C, Roush RT, Powles SB (1999). Herbicide resistance in weeds of southern Australia: why are we the worst in the world? In: Bishop A, Boersma C, Barnes CD (eds). 12th Australian Weeds Conference: Papers and Proceedings, Tasmanian Weed Society: Davenport, Australia, pp 454-459.

Preston C, Tardif FJ, Christopher JT, Powles SB (1996). Multiple resistance to dissimilar herbicide chemistries in a biotype of Lolium rigidum due to enhanced activity of several herbicide degrading enzymes. Pestic Biochem Physiol 54: 123-134.

Rajasekaran K, Grula JW, Anderson DM (1996). Selection and characterization of mutant cotton (Gossypium hirsutum L.) cell lines resistant to sulfonylurea and imidazolinone herbicides. Plant Sci 119: 115-124.

Shaner DL (1999). Crops modified to resist amino acid biosynthesis inhibitors. In: Singh BK (ed). Plant Amino Acids: Biochemistry and Biotechnology, Marcel Dekker: New York, pp 465-485.

Tardif FT, Holtum JAM, Powles SB (1993). Occurrence of a herbicide-resistant acetyl-coenzyme A carboxylase mutant in annual ryegrass (Lolium rigidum) selected by sethoxydim. Planta 190: 176-181. 